\title{
EXPERIMENTAL STUDIES ON THE ANTIGENICITY OF HOUSE DUST AND PROPERTIES OF ANTI-HOUSE DUST ANTIBODY
}

TOSHIO UCHIDA, SHUNKICHI BABA, YOSHIO SENOH, HIROSHI KAWADA TETSUII KATOH AND TERUO TAKASU.

Department of Otorhinolaryngology, Medical School, Nagoya City University, Nagoya

(Director: T. Takasu, M.D.)

As the precipitating antibodies in rabbits to house dust were considered to correspond to the blocking antibodies produced by hyposensitization treatment, rabbit anti-house dust antibody was used to investigate the antigenicity of house dust producing blocking antibody in human. The summary of the obtained results were as follows :

1) By the use of rabbit anti-house dust serum it was found that house dust extract contained at least three antigenic elements and the specific activity of the antibodies to house dust was displayed by the $7 \mathrm{~S}$ gammaglobulin and not by the $19 \mathrm{~S}$ macroglobulin fraction in radioimmunodiffusion test.

2) Fractionation of the house dust extract by gel diffusion and radioimmunoelectrophoresis disclosed that the protein fraction contained two antigenic components. Furthermore, one of these components was deprived of its antigenecity by the action of pronase but no antigenicity was demonstrated in polysaccharide fraction. On the other hand, Morris and his co-workers were unable to detect significant loss in skin reactivity to purified house dust fraction submitted to treatment with pronase.

3) Using mite extract and candida extract, cross reactions to anti-house dust serum were investigated with gel diffusion, but reactions were negative for both while Miyamoto et al. reported a close correlation between extract of house dust and considered mites as the main allergen in house dust.

4) From these results, the allergenicity of house dust in skin test and the antigenicity of house dust to blocking antibodies in man might be dissociated in some instances.

\section{A78-0019. 32860}

室内塵の抗原性ならびに抗室内塵抗体に関する実験的研究

名古屋市立大学医学部耳鼻咽喉科教室（主任：高須照男教授）

内田敏 夫・馬場 駿吉・妹 尾淑 郎

河田博・加藤哲二・高須照 男

\section{緒 言}

Kern $(1921)^{13}$ 扝よび Cooke (1922)22 が室内壁の抗原 性に着目し即時型アレルギ一患者の皮内反応で最初の陽 性例を記载して以来, 室内麼注アトピー性気道アレルギ 一疾患の重要なアレルゲンの一つにあげられるようにな つた。ことに本邦では欧米にくらべて花粉症が少い反
面，室内塺アレルギーに遭遇する機会がはなはだ多くそ の治療む隇感作療法が主流をなす傾向にある，ところが 室内塵は多価抗原であるためそのアレルゲン性が問題と なり幾多の研究がなされているのに対し，遮断抗体に対 する抗原性についての研究はあまりみない，そこで著者 らは減感作療法で主役を演ずると考えられる遮断抗体が 
conventional antibody である点より，家鬼抗室内麼沈 降抗体と対比しらると考兵これを作成し，種々の基磷的 検討を行い2〜3の知見を得たので報告する.

\section{実験材料ならびに方法}

\section{1 実験材料}

1）室内塵エキス

鳥居薬品上り提供を受けた室内麾エキス溶液 (1：10) Lot 26 ならびに同溶液の凍結乾燥末を(1:1) の濃度 に純水で調製したものを使用した。

2) 実験動物

成熟雄性家鬼で体重 $2 \mathrm{~kg}$ のもの3 羽を用いた。

\section{2 実験方法}

1）家鬼抗室内塺抗体の作成

室内塵エキス（1：10）を充分純水で透析したもの $1 \mathrm{ml}$ を Freund's complete adjuvant $1 \mathrm{ml}$ を等量混合し water in oil の状態にしたもの $2 \mathrm{ml}$ を家鬼の足蹠皮内に分割 注射した。 追加免疫は 2 週間々隔に $3 \sim 5$ 回皮内に分割 注射した. 最終感作後 7 日目に全採血し血清を分離し た.

\section{2）寒天ゲル内沈降反応}

Ouchterlony ${ }^{3)}$ の方法に従つた。すな的ち Wehring Werke 社製のアガロースを $\mathrm{pH} 8.6, \mu=0.15$ の veronal buffered saline に $1.2 \%$ 溶にかして plate 作成した。 沈降線の形成を一週間にわたつて観察した。

\section{3）免疫電気泳動}

Wehring-Werke 社製の agarose 並びに pure agar を 等量混じたものを $1.2 \%$ の割で $\mathrm{pH} 8.6, \mu=0.05$ の veronal buffer に溶解し用いた。

4) 抗室内塵抗体の Sephadex G 200 gel filtration Sephadex G 200 を $0.15 \mathrm{M}, \mathrm{pH} 8.00$ BBS (0.15M, $\mathrm{pH} 8.0$, borate buffer: $0.15 \mathrm{M} \mathrm{NaCl}, 1: 14$ ) で充分 bufferize し Pharmacia 製カラム $2.5 \times 95 \mathrm{~cm}$ になるよう に詰め, そこへ $50 \%$ 飽和硫安で塩析し BBS で充分透析 した抗宝内麼抗体の粗 $r$ グロブリン 3.0mlを流した。

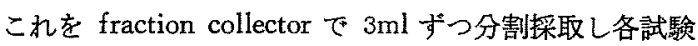
管の $280 \mathrm{~nm}$ に扔ける吸光度を日立分光々度計で剆定し た.

\section{5） ${ }^{181}$ 標識室内麘の作成}

尾上出の方法に従つた。すなわち室内塺エキス(1：10) を $0.15 \mathrm{M}, \mathrm{pH} 8.5$ の borate buffer で充分透析後, 蛋 白量 $690 \mu \mathrm{g} / \mathrm{ml}$ (BSA に換算) になるように同 buffer で 稀釈しこの $1.0 \mathrm{ml}$ を ${ }^{181} \mathrm{I}, 2 \mathrm{mCi}$ と反応させた。 ${ }^{131} \mathrm{I}$ 標識する際 New England Nuclear Corp 製の $\mathrm{Na}^{131} \mathrm{I}$ を chloramin $T$ で酸化して用いた，標識後 free の ${ }^{181}$ は No. 8/32の Visking tube を用い，三時間マグネチッ クスターラでかく找しながら透析したのち，外液をか えてさらに一夜透析し除いた。

6) radioimmunodiffusein 拉よび radioimmunoelectrophoresis

八本 ${ }^{5)}$ らの方法に準じて行つた。 その概要は第 1 図に 示す如くである。

7）室内麼エキスの分画法

室内歴エキス $(1: 1)$ を第 2 図に示寸如き方法で硫酸 アンモニウム処理，三塩化酢酸処理などのもとに分画を 行い，蛋白質分画ならびに多糖類分画を得た．又蛋白質 分画にプロナーゼおよびリゾチーム消化処理しその抗原 性の変化む検討した。

8）蛋白量ならびに多糖類量の測定

蛋白量は BSA 量に換算した Folin-Ciocalteau 変法

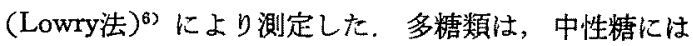
D-galactose (片山化学工業) 量に換算したフェノール硫 酸法 ${ }^{7)}$ で, アミ/糖には D-glucosamine hydrochloride （生化学工業）量に換算した Elson-Morgan 変法量で, ウロン酸には D-グルクロン酸ラクトン（東京化成工業） 量に換算したカルバゾール硫酸法9にによりそれぞれ測定 した.

\section{9）薄層ゲル沪過法}

Sephadex G 100拉よび G200 superfine を用い右田 ${ }^{10}$ の方法にしたがつて施行した．室内塵エキス（1：1）を 蛋白量 $10 \mathrm{mg} / \mathrm{ml}$ に迄浱縮し PBS $(0.15 \mathrm{M}, \mathrm{pH} 7.2$ phosphate buffer: $0.15 \mathrm{M} \mathrm{NaCl}, 1: 1)$ で充分透析しダ ル沃過した。

10）抗室内塺抗体の IgG 分画作成

DEAE cellulose (Brown 社製) を充分イオン化したの ち, $0.067 \mathrm{M}, \mathrm{pH} 8.5$ tris phosphate buffer で bufferize し $2.2 \times 40 \mathrm{~cm}$ のカラムに詰めて buffer を流し, $\mathrm{pH}$ メ ーターで流出する液が $\mathrm{pH} 8.5$ であることを確認したの ち，予め同 buffer で充分透析しておいた抗室内塺抗体

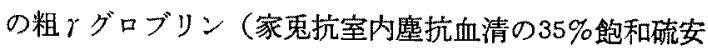
塩析したもの） $1 \mathrm{ml} /$ 分の流速で流した。この溶出液 を $8 \mathrm{ml}$ ずつ fraction collector で集め $\mathrm{OD}_{280}$ を測定し最 初に elute される peak を集め濃縮した。これが immunoelectrophoresis で pure な IgG であることを確認し k.

10）前項 IgG:分画の $\mathrm{CM}$ cellulose chromatography による細分画 


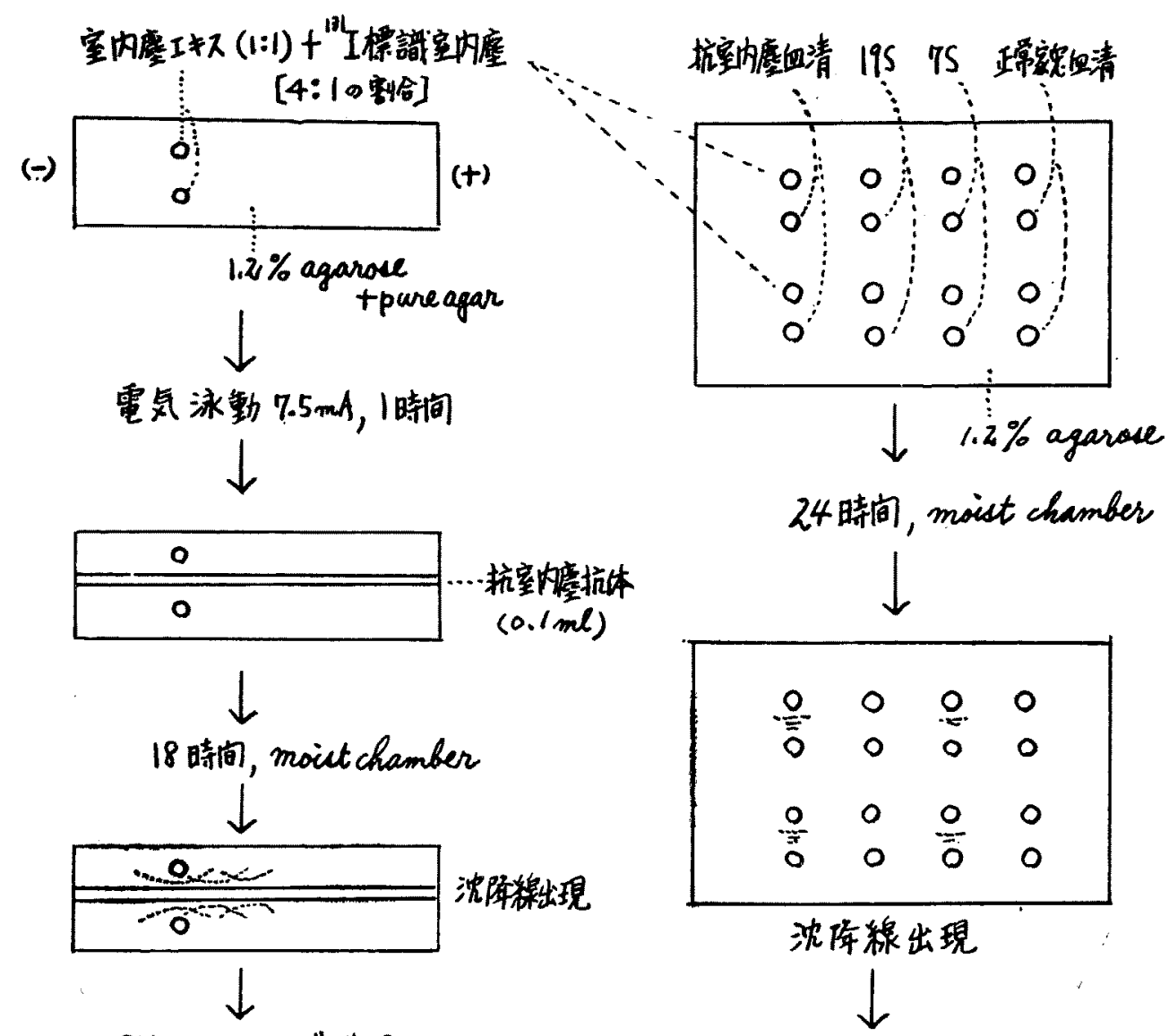

PH7.2 BBSで洗深

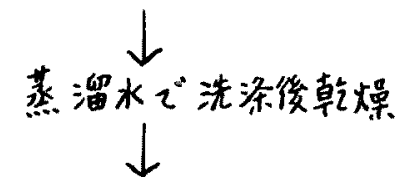

PH7.2 BBSで洗深

X線7xルム<smiles>C[As](C)(C)=[W]</smiles>

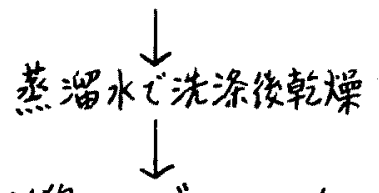

X線1须i゙ radioautography

現像

[第 1 图]

前項の記載方法により得た IgG 抗体を CM cellulose chromatography を用い net charge の差によりさらに 3 分画に細分した. CM cellulose (Brown 社製)をイオ ン化したのち, $0.06 \mathrm{M}, \mathrm{pH} 5.4 の$ acetate buffer で充 分に平衡化し， $2.2 \times 18 \mathrm{~cm}$ にカラムにつめ buffer を流 し完全に平衡化する.そこ一同 buffer で充分に透析し た IgG (100 mg) を流した。流速は $2 \mathrm{ml} /$ 分とし $10 \mathrm{ml}$ $\supset$ fraction collector で集め, 0.1M, pH 5.3 actate buffer, つずいて $0.5 \mathrm{M}, \mathrm{pH} 5.3$ acetate buffer と stepwise に elute して分画した.

\section{実験成綪}

1）家鬼抗室内塺抗体は gel diffusion で No 1, No3 の 2 羽が 3 本の沈降線を示し, No 2 では 2 本の沈降線 を示した，よって以後の実験成續は No 1, No 3 の血清 


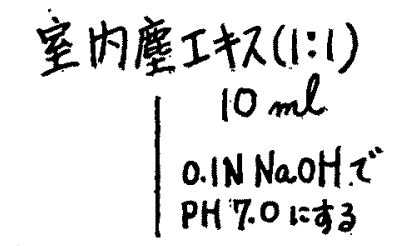

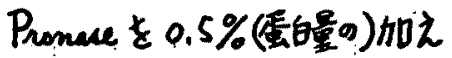
$37^{\circ} \mathrm{C}, 48$ 時间溥化

逞化3000r.p.m

15 分
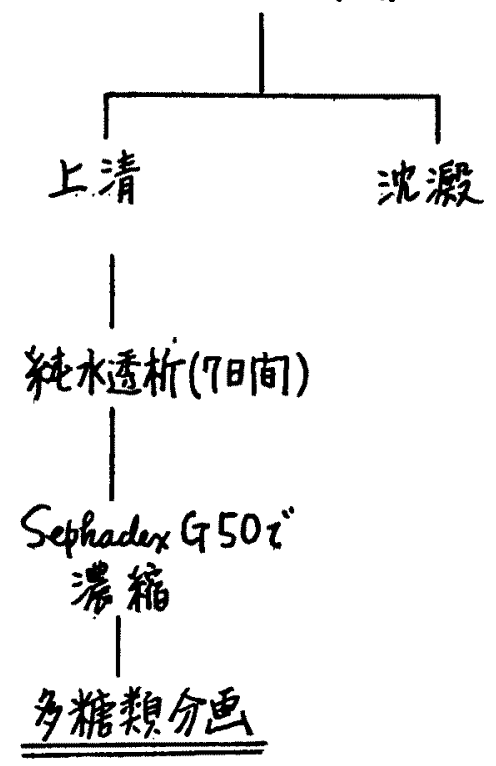

宾内麾I双(1:1)

$10 \mathrm{ml}$
慨和硫安
$10 \mathrm{ml}$

墶心゙3000r.p.m

15 分

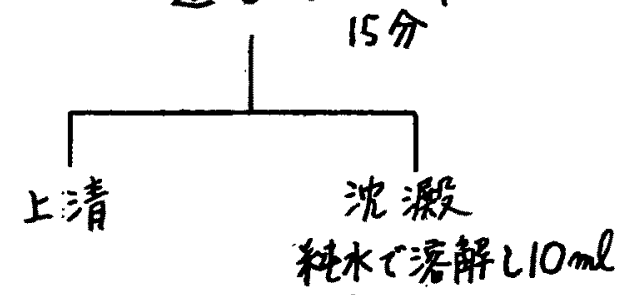

とする

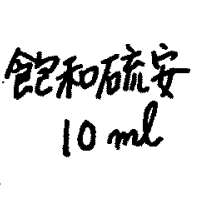

㟟心゙ 3000 r.P.m

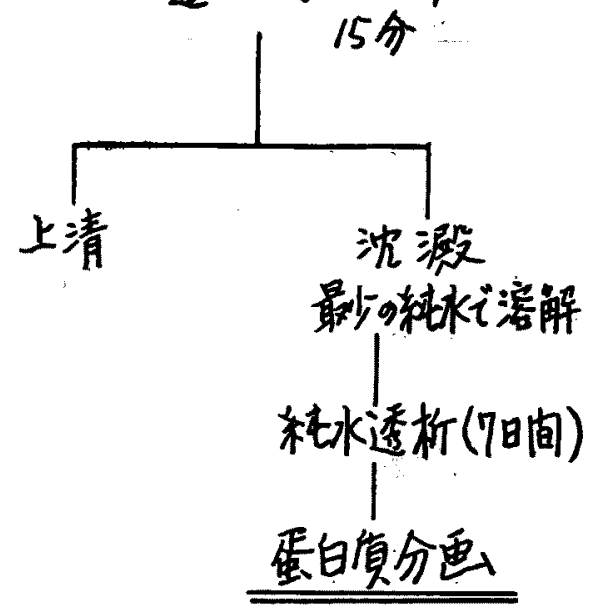

〔第 2 図〕

を使用して行つたものである（第3図）

2）室内歴エキス $(1: 1)$ 门 immunoelectrophoresis でも第 4 図に示す如く 3 本の沈降線の出現を見た。

3）抗室内歴抗体の Sephadex G200 gel filtration の 結果は第 5 図に示す如く三つの peakすなわち $19 \mathrm{~S}$ macroglobulin, 7S gamma-globulin および aloumin を得 た.この第一执よび第二 peak 集め濃縮し19Sで
$1 \mathrm{mg} / \mathrm{ml}, 7 \mathrm{~S}$ で $10 \mathrm{mg} / \mathrm{ml}$ (蛋白量) とした.

この各分画と double diffusion で室内塺エキス (1:1) と反応させたところ 7S 分画にのみ 2 本の沈降線を形成 した. さらに radioimmunodiffusion を行って見ても 19S分画には radioautography で radiaoactivity を検出で きず，7S 分画にのみ検出した.

4）室内塺エキスの分画は前述した如く行い，一応蛋 

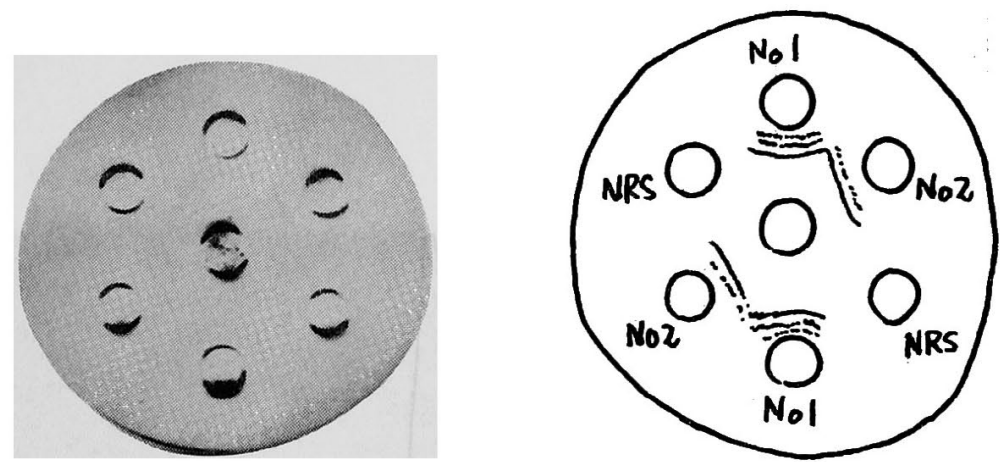

〔第 3 図〕

室内塵エキスと抗室内塵家鬼血清による寒天ゲル内沈降反応

No. 1 No. 2 抗室内塵家鬼血清

NRS 正常家鬼血清

第 1 表

\begin{tabular}{|c|c|c|c|c|c|}
\hline & 蛋 白 量 ${ }^{1)}$ & ヘキソース ${ }^{2)}$ & ウロン酸 ${ }^{3)}$ & ヘキソサミン ${ }^{4)}$ & 多糖類／蛋白質 \\
\hline 室内塵エキス（1:1） & $0.98 \mathrm{mg} / \mathrm{ml}$ & $3.7 \mathrm{mg} / \mathrm{ml}$ & $2.0 \mathrm{mg} / \mathrm{ml}$ & $0.02 \mathrm{mg} / \mathrm{ml}$ & 3.79 \\
\hline 蛋 白 質 分 画 & $2.30 \mathrm{mg} / \mathrm{ml}$ & $0.56 \mathrm{mg} / \mathrm{ml}$ & 0. $1 \mathrm{mg} / \mathrm{ml}$ & - & 0.24 \\
\hline 多 糖 類 分 画 & $0.13 \mathrm{mg} / \mathrm{ml}$ & $1.14 \mathrm{mg} / \mathrm{ml}$ & $0.7 \mathrm{mg} / \mathrm{ml}$ & - & 8.76 \\
\hline
\end{tabular}

1） Lowry 法 (BSA 換算） 2）フェノール硫酸法（ガラクトース換算）

3） カルバゾール法（グルクロノラクトン換算）４）エルソン モーガン変法（グルコサミン換算）

質分画ならびに多糖類分画とした．分析結果は第 1 表 示す如くであり，蛋白質分画にも多糖類を少量含有 ，一方多糖類分画にも少量の蛋白質を混じをもにお互 を無視できる程度に迄は分離しえなかつた。

5）室内塵エキス蛋白の分子量について Sephadex G 10 および Sephadex G 200 superfine 薄層ゲル沃過で べたところ，第6図に見る如くで室内塵蛋白の主成分 分布は人血清アルブミンより人 $7 \mathrm{~S}$ 分画にわたる幅広 分子量に分布していた.

6）室内塺エキスの蛋白質分画と抗室内塺抗体との間 は gel diffusion で 2 本の沈降線を認めたが, 多糖類 画には沈降線の出現を確認できなかつた．更に蛋白質 画にプロナーゼ処理を行うと沈降線は 1 本のみとなつ ところがリゾチーム処理を行つても沈降線の消失は
なく2 本認められた.（第 7 図）

7） ${ }^{131}$ I 標識室内塵の radioimmunoelectrophoresis $の$ 結果を第8図に示した。この図は immunoelectrophoresis とその radioautography とを並置したものである.これ によると immunoelectrophoresis で 3 本ある沈降線の5 ち radioautography ではそのうちの 2 本の沈降線にのみ radioactivity が検出されたが 1 本には radioactivity は 認められなかつた。

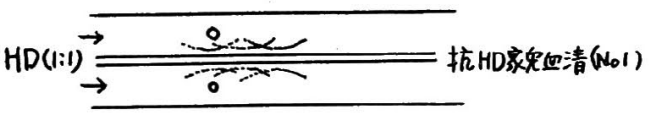

〔第 4 図】

HD (室内塵エキス) の immunoeletrophoreris 


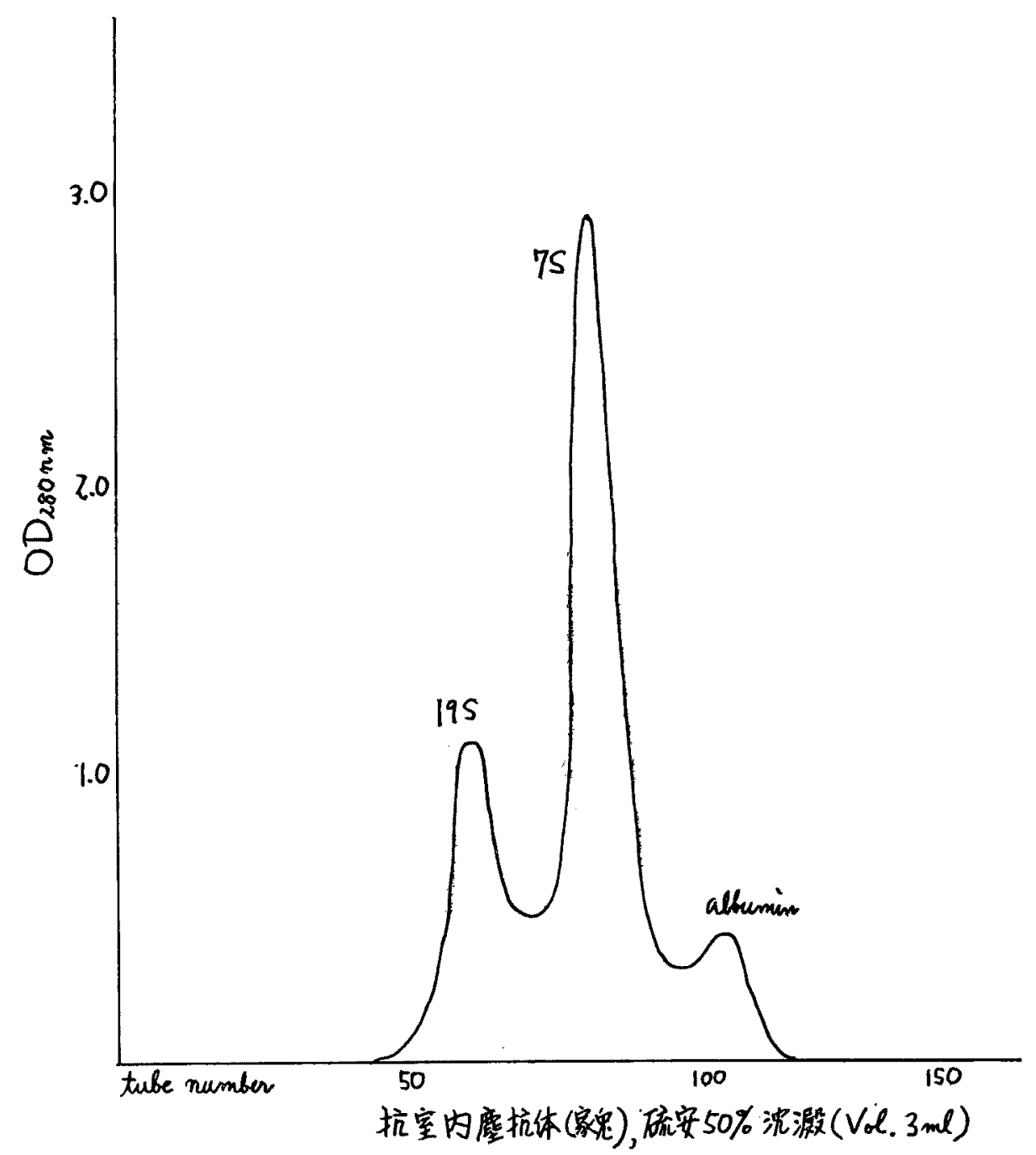

第 5 图

Column: Sephadex G 200, $2.5 \times 95 \mathrm{~cm}$

$\mathrm{pH} 8.0,0.15 \mathrm{M}$ borate buffered saline

流速 $12 \mathrm{ml} /$ 時間

8) Mite エキ又 $(1: 10)$, Candida エキ又 (1:10) （鳥居薬品提供）と抗室内塺抗体との交文反応性を double diffusion test で調べたがいずれも陰性であつた。

(第9図)

9) 抗室内塵抗体の $\operatorname{IgG}$ 分画を CM cellulose chromatographyにより stepwise elution で細分画して見る と第6図の如き［I][II][II]分画に細分できた。各 分画を集め濃縮しこれを immunoelectrophoresisで見る
と第10図の如くなり IgG が細分されていることが分つ た. 次に各分面の蛋白濃度を $5 \mathrm{mg} / \mathrm{ml} と し$ double diffusion で抗体活性を確めたところ [II] [III]分画に 沫降線を嚎めた。

\section{絰括ならびに考按}

室内應の抗原性の追求を目的として実験的に抗室内鷹 抗体を作成し各種室内椟エキス，室内塵エキス精製分 画，あるいは室内塵組成物質などの抗原性ならびに交叉 


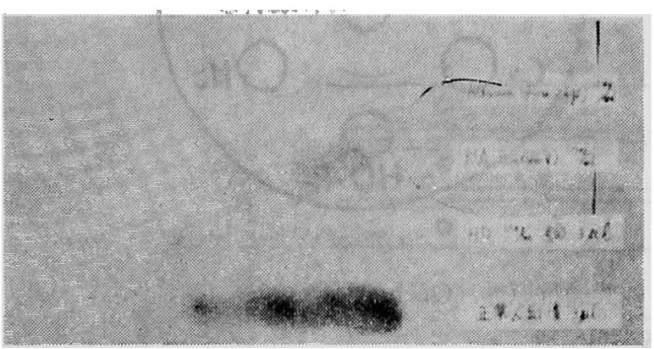

第 6 図

HD (室内塵) の薄層ゲル濾過

Sephadex G 200 sf.
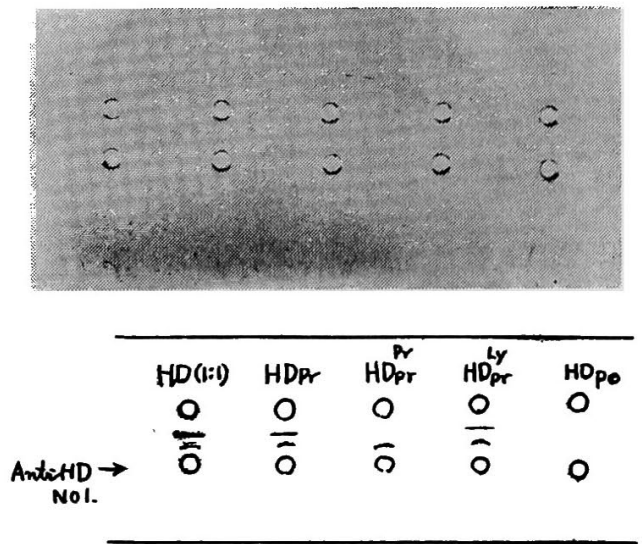

第 7 図 室内塵各分画の抗原性 (double diffusion) HD (1:1) …室内塵エキス (1:1)

HDPr …室内塵蛋白質分画 $\mathrm{HD}_{\mathrm{Pr}}^{\mathrm{Pr}} \cdots$ 室内塵蛋白質分画 (プロナーゼ消化) $\mathrm{HD}_{\mathrm{Pr}}^{\mathrm{Lz}} \cdots$ 室内塵蛋白質分画 (リゾチーム消化) HDPo …室内塺多糖類分画

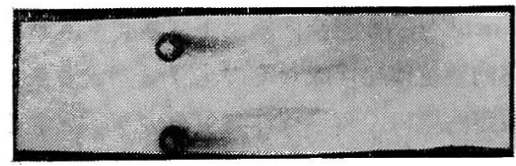

(I)

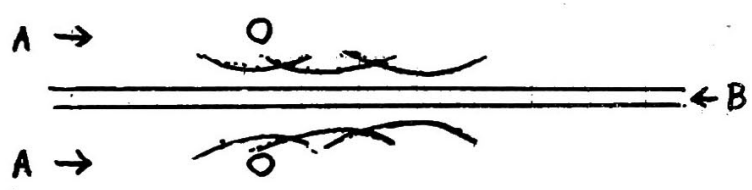

(2)

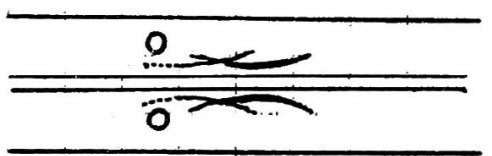

第 8 图

A : 室内塵 $(1: 1)+{ }^{131}$ 標識室内塵 [4:1 $の$ 割合 $]$

B: 抗室内塵家鬼血清 (No. 3)

1) 室内塺の immunoelectrophoresis 2) radioimmunoelectrophoresis 

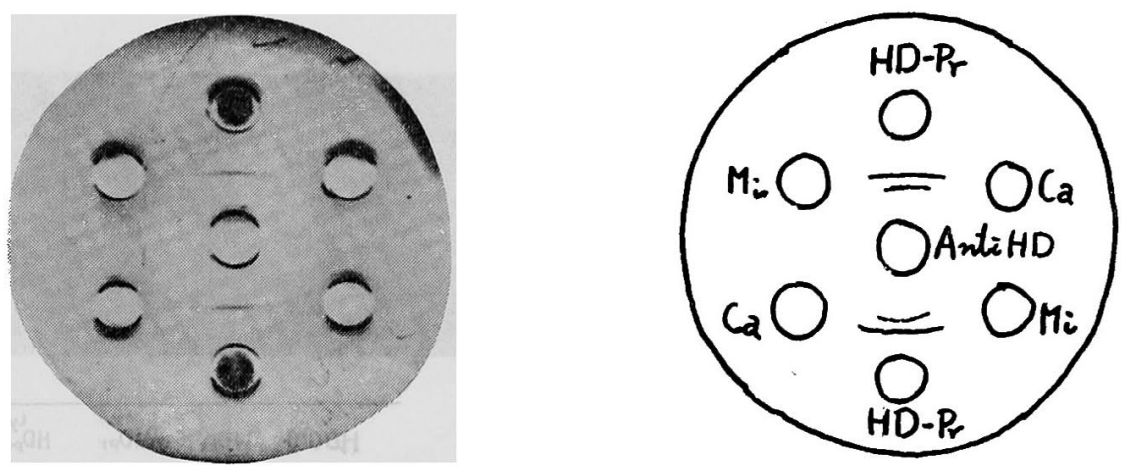

第 9 図

HD (P.r) と Candida 捛よび Mide の共通抗原性 (Ouchterlony)

HD-Pr：室内塵の蛋白質分画

$\mathrm{Ca}$ : Candida エキス

Mi: Mite エキス

反応性を gel diffusion などで検索したり, 人室内塵】 レルギーに扔ける活性部位（アレルゲン活性）を skin test で調べ対比した研究は数多い。すなわち Wodehou$\mathrm{se}^{11)}$, Phillips ${ }^{12)}$ らは家鬼抗室内塵抗体を作成し gel diffusion で室内塵の抗原性が三つあることを明らかに し，いずれの室内應でも一本のシャープな沈降線を寒天 ゲル内に認めこれを major antigen と考えた. Hanissi$\mathrm{an}^{13)}$ らも数社の室内塵エキス製品で家鬼抗室内塵抗体を 作成し各室内塺間に強い交叉反応性があるといってい る. Loeb ${ }^{14)} ら は$ 粗室内塺および精製室内塵を用い家鬼 に抗室内塵抗体を作成しその沈降線の数より, 精製室内 塺は粗室内塺にくらべ抗体産生をより刺激するとのべて いる. Follensby ${ }^{15)} ら は$ 精製室内歴を用い家鬼を免疫し その抗血清で吸収した室内塵による skin test を人に行 い, 室内栕の家鬼における抗原性と人におけるアレルゲ

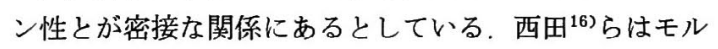
モット抗室内塵抗体を用い室内塺の抗原分析を行い, 室 内塵の多糖類分画を Sephadex G 50 gel filtration で分 離し, これがモルモット血清に対し double diffusion で 2 本の沈降線を示し人皮内反応で強く陽性を呈したとの べている. 柿沼 ${ }^{17)}$ は家鬼抗室内塵抗体を作成し gel diffusion で室内塺の精製分画との反応性を検討 し, 家鬼 沈降抗体と反応する室内塺分画は多糖類であるとしまた 人皮内反応で陽性を示すアレルゲンと共通抗原を持つと のべている。一方伊藤 ${ }^{18)} ら{ }^{131}$ 標識室内塵による抗室 内塺家鬼抗体の研究で室内歴の家鬼に扔ける抗原性は少
なくとも 4 つあり Middlebrook-Dubos 法による感作赤 血球凝集反応は陰性であるとの心゙その抗原性を蛋白質部 分にあるとしている．著者らの室内塵エキス（1:1）の 分析結果で見ると，蛋白量にくらべ多糖類の分量が多い が, 後述する如く蛋白質部分に抗原性が強、成績を得 た. そして Sephadex G 200 superfine による薄層ゲル ろ過によると室内塵エキス（1：1）に含まれる蛋白は人 血清アルブミンより小さい分子量より人 IgGの分子量迄 にひろがつていることが判明した．しかし家兔に対する 室内塵の抗原性と人におけるアレルゲン性との対比は人 室内塵アレルギーで証明されるアレルゲン性が IgE 抗体 と反応した結果で示されるのに対し, 家象における室内 塵の抗原性が IgG抗体と反応したものである点で無理が あると思われる。そこで著者らは家鬼抗室内塵抗体が Sephadex G 200 gel filtration で分画された 7S 分画に 活性を有しさらに radioimmunodiffusion でも $19 \mathrm{~S}$ には 抗体活性を認めなかつたことより IgG 抗体に属すると 考えた.これはむしろ人室内塵アレルギー患者に減感作 療法を行つた際産生される遮断抗体 (IgG 抗体) と比較 しらることを意味する. 著者らの作成した抗室内塵抗体 に対して室内塵は 3 種の抗原性を示しそのらち2 種は蛋 白質抗原と考えられた。 すなわち蛋白質分画に gel diffusion で 2 本の沈降線を認め, ${ }^{131} \mathrm{I}$ 標識室内塵の radioimmunoelectrophoresis でも2本に radioactivity を証 明できたからである.つぎにこの蛋白質分画を Pronase で消化処理したものを抗原として gel diffusion を行つ 


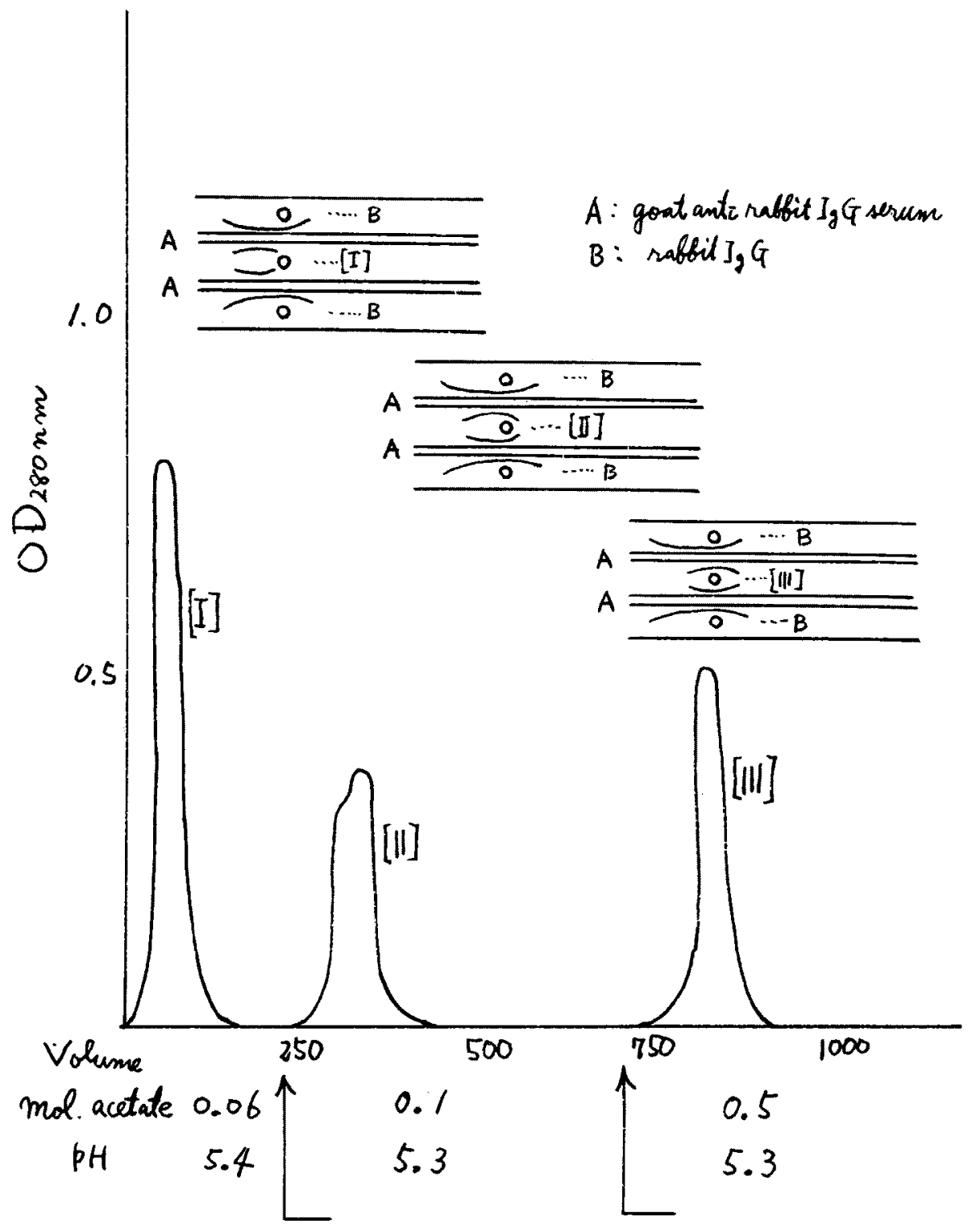

第10図

抗室内塺抗体の IgG 細分画 (IgG 100mg)

$\mathrm{CM}$ cellulose chromatography

column： $2.2 \times 18 \mathrm{~cm}$ 流速 $2 \mathrm{ml} /$ 分 
て見たところ，未処理分画が 2 本の沈降線を示したのに 対し，1本となり1つ抗原性の消失を認めた．一方室内 麾エキスを精製し人に対するアレルゲン性を追求した文 献法数多く Boatner ${ }^{19)}$, Sutherland ${ }^{20)}$, Campbell ${ }^{21)}$, Бを 始めとし, 以後 Gross ${ }^{211}$ ，Berrens ${ }^{23), 24) ， V e r s i e}{ }^{25)}$, Guibert ${ }^{26)}$ らとつずき，いずれもアレルゲン性の高、分画を 得ている、更に Berrens ${ }^{27)}$ は精製室内塺をトリプシ ン， $\alpha$-キモトリプシンで消化してもそのアレルゲン性注 不変であつたとのべ，Morris ${ }^{28}$ らは Pronase を用い精 製室内塵のペプタイド部分を $66 \%$ 分解しても，それを用 いた skin test で反応性の低下を全く認めなかつたと報 告している。このように人室内痤アレルギーに対するア レルダン性は種々の蛋白分解酵素では変化しないとされ る、このことは著者らの家鬼沈降抗体に対する室内塵 が変化をらけ一部抗原性を失つた点とくらべ大きな違い である，人室内應アレルギー患者の遮断抗体を家鬼沈降 体抗と対比して見ると室内魔の遮断抗体に対する抗原性 と reagin に対するアレルゲン性とが一部解離する可能 性を示唆する。つぎ室内塵エキスとそれに含まれてい る物質との関連性から检討した文献に $2 \sim 3$ ふ九て見る と，まず家鬼沈降抗体比対する抗原性より，Kantor ${ }^{28}$ は 室内塺と真菌類 (Hormodendrum) との交叉性を認め, 青木 ${ }^{300}$ 柱室内塺とアスペルギルス，カンジダとの共通抗 原性を，吉田 ${ }^{31}$ は細菌類との共通抗原性を確認できたと 報告している。一方人に対するアレルゲン性を skin test あるいは吸入誘発試験をもとにし検討した文献では。

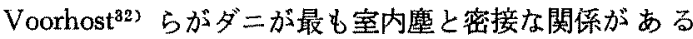
とのべて以来, ダニが室内歴アレルゲンの重要な成分と して脚光をあびてきた，以後 Mitchell ${ }^{53)}$, Spieksma ${ }^{34)}$,

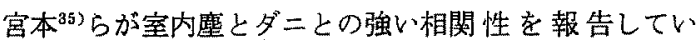
る. 大島 ${ }^{36}$ は本邦の室内塺にもその供給源により差はあ るがいずれも室内塺中のダニの主要種は Darmatophagoides 属のダニであるとのべている. Maunsell ${ }^{37) ~ ら は ~}$ mattress dust 中に pteronyssinus が最も多く, 室内糜 との相関性が skin test の上で高いとの心゙, Pepys ${ }^{88)} ら$ 注 D. culinae が室内塺と相関性を持つと報告している。 島田 ${ }^{89)}$ らは D. farinae と室内歴との抗原性の一致を鼻 アレルギ一患者を用い皮内反応，鼻粘膜誘発反忘， P-K 反灾により検討し高い陽性一致率を見ている. Stenius ${ }^{40)}$ らは radioallergosorbent test を用い D. culinae と室内 㕍とはたとえ skin test で相関がなくとも，それぞれの specific IgE 抗体とはよく相関するとのべている，著者 らはカンジダエキス (Candida albicans) および Mite
エキス（D. farinae）と室内痤との共通抗原性を ring test, gel diffusion test で抗室内痤家鬼抗体を用いて検 討したが，共通抗原性を確認できず室内歴の主要抗原と は考えられない結果を得た。このことはダニが人室内應 アレルギーに対する主要アレルゲンと考えられるのに対 し, 逘断抗体を産生せしめる主要抗原はダニやカンジダ 以外の他の物質が想定されることを示している．人室内 麼アレルギー患者の遮断抗体の証明は非常に困難で間接 赤血球凝集反応，モルモットにおける PCA 反忘などで 測定しており，河田 ${ }^{41}$ によるとモルモットPCA を用い 室内糜アレルギー患者の遮断抗体は IgG 抗体の中でも 中間の易動度を持つ分画に活性が高いと報告している。 著者的家鬼沈降抗体の IgGを CM chromatography で細分画し，gel diffusion を用い活性部位を検討したと $こ ろ$ moderate fast IgG 分画に活性が高いといら結果を 得ている，さらにモルモット抗室内塺抗体なども作成し 家鬼抗室内塺抗体，人室内㢈アレルギ一患者の遮断抗体 に対比して室内摩の抗原性を追求したいと考えている。

\section{参考文献}

1) Kern, A.. Dust sensitization in bronchial asthma Med. Clin. North. Amer. 5; 751-755, 1921.

2) Cooke, R.A.. Studies in specific hypersensitiveness IV. New etiologic factors in bronchial asthma. J. Immunol. 7 ; 147-162, 1922.

3) Ouchterlony, Ö: In vitro method for testing the toxin-producing capacity of diphtheria bacteria. Acta. Pathol. Microbiol. Scand. 25; 186-191, 1948.

4）尾上董：蛋白抗原の ${ }^{181} \mathrm{I}$ による標識法。免疫実験 操作法, 日本免疫学会糄，41-42, 1971.

5) Yagi, Y., Maier, P., Pressman, D., Arbesman, C. $E$. and Reisman, R.E.: The presence of the ragweed binding antibodies in the $\beta_{2} \mathrm{~A}^{-}, \beta_{2} \mathrm{M}^{-}$and $\gamma$-globulin of the sensitive individuals. J. Immunol. $91 ; 83-89$, 1963.

6) Lowry, O.H., Rosebrough, N.J., Farr, A.L., and Randall, R.J.: Protein measurement with the folin phenol reagent. J. Biol. Chem. 193 ; 265-275, 1951.

7) Dubois, M., Gilles, K.A., Hamilton, J.K., Rebers, P.A. and Smith, F.: Colorimetric method for determination of sugars and related substances. Anal. Chem. 28 ; 350-356, 1956.

8) Belcher, R. Nutten, A.J. and Sambrook, C.M.: The determination of glucosamine. Anaiyst. 79; 201-208, 
1954.

9) Dische, Z.: A modification of the carbazole reaction of hexuronic acids for the study of polyuronides.

J. Biol. Chem, $183 ; 489-494,1950$.

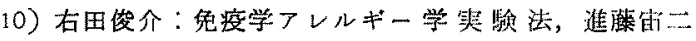
絀, 文光堂. $732-735,1971$.

11) Wodehouse, R.P.: Analysis and standardization of house dust by gel diffusion. Ann. Allergy. 12 ; 363$374,1954$.

12) Phillips, L.A, and Northey, W.T.: Antigenic components of hnuse dust allergens. J. Allergy. 36; 303-306, 1965.

13) Hanissian, A.S., Roane, J.A., Triplett, F. and Crawford, L.V.: A study of the antigenic relaitonship various house dust antigens. Abstract. Ann. Allergy, $23 ; 210-210,1965$.

14) Loeb, L.J., Larose, C. and Siddiqui, A.I.: Immunological studies of house dust. Abstruct. J. Allergy. 37 ; 107-107, 1966.

15) Follensby, E.M, Lowell, F.C. and Schiller, 1.N.: Studies on the house dust allergens I The relations between the antigens and allergenic components. J. Allergy. $27 ; 103-112,1956$.

16）西田勝, 豊島協一郎, 重居紅葉, 蒲生逸夫: 家屋䵇 の抗原分析.フレルギー，17；496-497，1968.

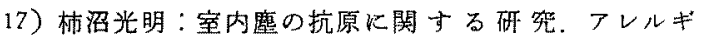
一, $13 ; 173-182,1964$.

18）伊藤治，青木良雄，進藤宙三，大城晶子： ${ }^{121}$ 装 識室内塵に上る抗室内塵抗体の梌索一その基礎的研 究一アレルギー, $17 ; 551-557,1968$.

19) Boatner, C.H., Efron, B.G. and Dorfman, R.I.: Preparation of purified house dust extracts. Science, $91 ; 389-390,1940$.

20) Sutherland, C.: The preparation of house dust extracts. Brit. Med. J. 2 ; 280-280, 1942.

21) Camplell, D.H., Silver, D.Z, and Vannier, W. $E$.: Immunochemical studies of house dust allergen. Abstract. J. Allergy, 25 ; 73-74, 1954.

22) Gross, $R$.: Fractionation and chemical investigation of house dust allergens. Int. Arch. Allergy, 23; 321 $-330,1963$.

23) Berrens, L. and Young, E.: Purification and properties of house dust allergen. Int. Arch. Allergy,
$19 ; 341-359,1961$.

24) Berrens, L., Morris, J.H. and Versie, R.: The complexity of house dust, with special reference to the presence of human dandruff allergen. Int. Arch. Allergy, 27 ; 129-144, 1965.

25) Versie, R.: Etude comparative des procédés d' extraction et de purification des allergèns de poussières de maison. Acta. Allergy. 20;15-37, 1965.

26) Guibert, L. et Causse-Combes, R.: Activité allergénique des fractions obtenues par chromatographie de l'extrait de poussière de maison. Ann. Int. Pasteur, 108 ; 579-601, 1965.

27) Berrens, L.: Studies with purified house dust allergen and observations on the nature of its polypeptide constituent. Clin, Chim. Acta. 8 ; 457-463. 1963.

28) Morris, J.H., Berrens, L. and Young, E.: : The carbohydrate moiety of house dust allergen. Clin. Chim. Acta. $12 ; 407-414,1965$.

29) Kantor, S.Z. and Wasserman, L.. Studies on the antigenicity of molds and house dust. Israel. J. Med. Sci. 2 ; 534-540, 1966.

30）青木良雄，伊藤幸治，進滕宙二，火城晶子：House dust と真菌菌体成分々の関連性。アレルギー，17； 501-501, 1968.

31）吉田钽久：室内栕飞関する研究，室内麼と Staphy. lococcus aureus 菌体成分の交艮反応性汇関する研究。 フレルギー、19;22-30, 1970.

32) Voorhorst, R., Spieksma-Boezeman, M.I.A. and Spieksman, F.Th.M.: Is a mite (Dermatophagoides sp.) the producer of the house dust allergen? Allergie Asthma, 10;329-334, 1964.

33) Mitchell, W.F., Wharton, G.W., Larson, D.G. and Modic, R.: House dust, mites, and insects. Ann. Allergy, 27 ; 93-99, 1969.

34) Spieksma, F.Th.M, Miyamoto, T., Oshima, S. and Mizuno, K.: Cultivation of house dust mites. Correspondence, J. Allergy 43;151-154, 1969.

35) Miyamoto, T., Oshimx, S., Ishizaki, T. and Sato, $S$.: Allergenic identity between the common floor mite (Dermatophagoides farinae Hughes, 1961) and house dust as a causative antigen in bronchial as thma. J. Allergy, $42 ; 14-28,1968$. 
36) 大島司郎：室内塵中の日本産チりダ=屈 (Mealia) 3 㮒飞ついて (Acarina: Pyroglyphidae) 郝生動物, $19 ; 165-191,1968$.

37) Maunsell, K., Wraith, D.G. and Cunnington, A. M.: Mites and house-dust allergy in bronchial asthma. Lancet 1, 1267-1270, 1968.

38) Pepys, J., Chan, M. and Hargreave, F.E.: Mite and house-dust allergy. Lancet 1, 1270-1272, 1968.

39）島田哲男，石川荐，宮下久夫，藤田洋右：鼻フレ ルギーに関する最近の研究（第3報）鼻フレルギー患 者におる house dust $と$ mite (Dermatophagoides farinae) との抗原性の一致について，日耳鼻，76；
1368-1372, 1973.

40) Stenius, $B$. and Wide, L.: Reaginic antibody (IgE), skin, and provocation tests to Dermatophagoides culinae and house dust in respiratory allergy. Lancet 2 ; 455-458, 1969.

41) 河田博;鼻アレルギーの臨床的ならびに実験的研 誃補遗 名市大医誌，25；89-123，1974。

御校閱いただきした恩師高須昭男教授に深謝致しま

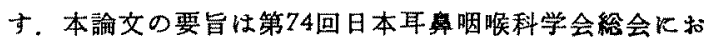
いて発表した。

（原稿受付 昭和49.7.29日） 